\title{
Necessary And Sufficient Conditions For Post-Communist Communist Reform
}

\author{
George Lee, (E-mail: leespeaking@gmail.com), San Francisco State University
}

\begin{abstract}
The results of post-Communist reforms in the Central Europe Economies have been less than ideal; the republics of the former Soviet Union have fared even worse (Lee, 2006). Necessary and sufficient conditions for post-Communist reforms include those needed to design logical and viable policies, those required to protect viable policies from unreasonable attacks, and those necessary to ensure orderly implementation with the smallest risk to the country's economic well being. At the least, reform policies must be theoretically rigorous and supported by comprehensive empirical evidence. Moreover, even policies proven to be effective in bring economic prosperity in other countries need to be tested in small scale, in-country proving grounds before they are expanded to the entire country. Finally, however viable the proposed policies, they cannot be implemented without the explicit approval and involvement of the country' political leaders.
\end{abstract}

\section{INTRODUCTION}

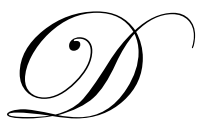

(Lee, 2006).

espite claims of miraculous economic performances by the designers and implementers of postCommunist economic reform policies, the results of post-Communist reforms in the Central Europe Economies have been less than ideal; the republics of the former Soviet Union have fared even worse

While criticism of post-Communist reforms is not wanting, few have come up with alternatives to the policies which have been used. Necessary conditions for post-Communist reforms include those needed to design logical and viable policies, those required to protect viable policies from unreasonable attacks, and those necessary to ensure orderly implementation with the smallest risk to the country's economic well being. Explicit in the name of this topic -- the necessary conditions for post-Communist reforms -- is that the country has already discarded communism. At the least, reform policies must be theoretically rigorous and supported by comprehensive empirical evidence. Moreover, even policies proven to be effective in bring economic prosperity in other countries need to be tested in small scale, in-country proving grounds before they are expanded to the entire country.

In what follows, I first discuss what constitutes effective post-Communist policies.

\section{EFFECTIVE POST-COMMUNIST REFORM POLICIES}

The designing effective post-Communist policies must begin with the identifying of the key problems of postCommunist transformation. Then the policies must be specifically designed to resolve the problems.

The key problem of post-Communist transformation is to achieve economically efficient and fair privatization. Economically efficient means moving towards the optimization of the use and allocation of scarce resources. For example, high unemployment or underemployment means zero or under utilization of resources, respectively, which obviously does not optimize the use of resources: the result, a smaller than achievable economic pie, which however cleverly it is sliced, may end up starving rather than enriching people. "Fair" is the antithesis of the fact that many of today's CEOs in post-Communist countries are yesterday's Nomenclatura. 
Operationally, the goal of the optimization of the use of resources can be achieved by stimulating the economy to full-employment equilibrium. One criticism of the full employment objective is that it ignores inflation. True, using demand management policies to get full employment will result in some increase in inflation, but this is not necessarily bad. In the extreme case of the Great Depression, while increasing aggregate demand made inflation less negative or even positive, no responsible policy maker could argue that this would be a rational reason to not increase demand. Moreover, in an economy with some unemployment, the increase in inflation, will be less than that predicted by the simple quantity of supply theory, because of the increase in real output and alleviated by the velocity of circulation of money. Moreover, in putting unemployed resources to work, the cost to society is zero. The end result of having an economy at fullemployment equilibrium is that the economic pie will be larger and people's real income will rise.

In assessing the economic cost/benefit of inflation versus unemployment, it is important to understand that inflation is essentially a distribution problem. Often the choice is between having some inflation and a larger economic pie (i.e. higher real income/capita) vs. little or no inflation and a smaller economic pie (i.e. lower real income). While volumes have been written about the theoretical possibility of a little inflation causing a lot of inflation, there is little empirical evidence confirming the validity of these theories.

Bankers often argue that if there is inflation, achieving "long-run, stable economic growth" is impossible. The theoretical logic or empirical validity of this statement is unclear. In contrast, attaining full employment, besides fully utilizing resources, also stimulates investment. In booming economies, producers--pushed to produce more and better products to satisfy demand -- buy more machinery, build more factories and acquire more advanced technology. With more machinery and factories, the capital-labor ratio increases, raising productivity and lowering production costs. Using more advanced technology in machinery and factories also improves productivity and lowers production costs; the decreases in production costs increase supply, bringing down inflation and increasing economic growth. Thus, having a full employment economy, in the long term, will expand the economy and shrink inflation; in other words, long-term, stable economic growth. It is the stuff of economic development.

Hence, even if inflation were the monster that bankers use to scare their children to sleep, the best way to deal with possible distribution inequities of inflation and not shrink the economy is to make some fixed incomes variable by indexing them to the consumer price index. In the United States, the indexing of social security payments to beneficiaries does exactly this.

The problem with fighting inflation with deflationary economic policies is that the economic/social losses from unemployment and foregone economic growth usually exceed any benefits, perceived or real, from achieving low or zero inflation. Clearly some International Organizations instrumental in post-Communist economic reforms recognize that their recommended policies will result in shrinking economies and high unemployment; case in point Poland's 18.3 unemployment rate. Indeed these organizations invented the concept of "social safety net" to deal with the symptoms of their post-Communist economic policies. Would it not be better to change the key objective of their post-Communist economic policies so that social safety nets are not needed? Battling inflation, and if there is no or little inflation, to stage preemptory attacks on inflationary tendencies, have usually resulted in raising unemployment and shrinking the economy. What has happened in the republics of the former Soviet Union and the post-Communist countries in Central Europe are cases in point.

The claim that simply letting market forces determine what happens in the economy is all that is needed to bring full economic efficiency to post-Communist countries would be true if all markets in post-Communist countries were innately competitive, and if their economies were kept at full employment equilibrium. In fact, all markets in Communist countries were state createe monopolies, and only a few of them are innately competitive. Baumol (1964) pointed out that competitive markets, naturally tending toward the point where price equals marginal cost, meets the first order condition for the maximization of total social economic welfare. Baumol's elegant analysis, however, implicitly assumes that the economy is at full employment. Indeed, this unwarranted assumption is what caused the world to fester in the Great Depression for more than 10 years. Thus, the correct conclusion from Baumol's analysis is that the equivalence of price and marginal cost is a necessary but not sufficient condition of the maximization of total social economic welfare. 
Baumol's analysis, however, pierces to the nub of the privatization issue, which is: the key criterion for efficient privatization is the market structure; innately competitive markets should be privatized without controls; innately noncompetitive markets can be privatized later, but with both price controls and anti-trust safeguards; to achieve maximum total social economic welfare. Prices in these markets should be controlled as close to marginal cost as possible and the economy should be kept at full employment equilibrium.

In the design of post-Communist reform policies, then, the first step is to recognize that efficient and fair privatization is the first and most important issue. By efficient privatization, we mean that, at the least, the prices in the markets privatized should be equal or close to marginal cost. Competitive markets will tend to go towards this point; non competitive firms need to be controlled by public price commissions to help them reach the point where price equals marginal cost. In terms of fairness, to bring about fair privatization, it is blatantly unfair to dole out huge portions of large companies to their former managers. Without efficient and fair privatization, all other post-Communist reforms will be just fluff. Even with efficient and fair privatization, however, post-Communist reforms would fail unless the economy operates at full steam.

Viable privatization addresses two flaws of communism, the absence of a linkage between contribution and reward and the lack of demand in its economic system. With no link between contribution and reward in state-owned enterprises, management and labor have no incentive to work. In Russia, efficiency in private plots are 30 times more efficient than communal properties. Without demand signals in the economic system, state-owned factories produced tanks and bombs while people starved. Similarly, in North Korea, more than a million people starved to death between 2002 and 2004 while the North Korean government was building nuclear bombs. Efficient and fair privatization will increase productivity, enhancing resource utilization. Also, since private firms will produce what the people want and need, resource allocation will be improved.

In sum, Marx's "solution" to the problems of the industrial revolution -- "no private ownership" -- turned out to be the definitive problem of Communism. Even if efficient and fair privatization were effected, however, transformed economies could end up where the western economies were in 1930, in an economic depression.

The second goal of post-Communist economies is to maintain, full-employment economies, not by giving people jobs, but, with stimulative fiscal/monetary policies, creating economies that are so robust everyone willing to work at the going wages can find a job. In economic depressions, all firms, state-owned and private, fail. In vibrant economies, private firms flourish and state-owned firms survive. In recessionary economies, even if ownership reforms were perfectly designed, private and state-owned firms would still fail.

We have identified two key goals problems of post-Communist reforms. A third issue is the direction of economic development. For small economies, e.g. less than 30 million people, exports are the most efficient engines of growth, since domestic economies are too small to bring about sustained economic growth. Large economies, e.g. 100 milliion or more, should use its large domestic market as its engine of growth. Even relatively large economies, when they are poor, will likely have to depend on exports as their engines of growth until their economies become prosperous. These economies, however, must systematically increase the role their domestic markets as their engines of economic growth.

The next step is to design policies that will solve these problems. A key question is, "How do we know that the policies will work?" To ensure that the policies designed will solve the problems, the policies must be designed to resolve the problems of post-Communist economies, and they must be rigorous theoretically and supported by comprehensive empirical evidence.

To be theoretically rigorous, the policies must be mathematically correct and logically consistent; being supported by comprehensive empirical evidence means that the policies have worked time and again, year after year, and in country after country. That is, the policies must be "proven" policies. 


\section{PROTECTION AGAINST UNREASONABLE CRITICISM}

Reforms -- no matter how relevant to existing problems, how sound theoretically and solid empirically -- can be brought down by unreasonable criticism. Reasonable criticism, even if not constructive, should always be considered and then used to improve the policies. Unreasonable criticism, if not neutered before they start, will stop reform. What has typically happened in post-Communist countries is that the leaders laud their economic accomplishments, no matter how reasonable the criticism or how bleak the economic conditions of their country. These leaders are usually voted out of office, often by former Communists, unless they maintain their power with the military and/or police. To obviate unreasonable criticism before they start, policy makers must create a roadmap of the reforms: the policies, the expected results, a schedule of the expected results, expected problems and the causes and cures of these problems.

Once the policies have been designed and the roadmap of the reforms has been drawn, then policy makers must openly discuss these policies regionally, nationally and internationally. Discussion will not be lacking as Communists and former Communists are not known to be shy about offering criticism.

In these discussions, policy makers should first state post-Communist reforms' goals -- effecting efficient and fair privatization and maintaining full-employment -- and explain the reasons for these goals. Some will oppose these goals, at which point policy makers should ask the critics for their proposed goals. Moderators should point out that if critics do not offer alternative goals, they are implicitly accepting the reform policies' goals.

Those offering alternative goals should be required to explain the reasons for their proposed goals. If they can show that their goals are worthy of consideration, then policy makers should consider them. If their goals are complementary to the policy makers' goals, then these goals should be included in the reforms. If these goals prove superior to the policy makers' goals, then these goals should replace the policy makers' goals. If those goals are would worsen rather than improve economic performance, then they should be rejected. It is all about which policies are best and not about whose policies are best. Since many can criticize, but few can offer alternative goals or be able to prove that their goals are superior, this process would diminish the power of unreasonable criticism now and in the future.

Reformers should then present their policies for attaining the goals and explain the rationale for these policies. Critics of the policies should be asked for their proposed policies. Moderators should again point out that those not offering alternative policies are implicitly accepting the policies. Proposed alternative policies equal to, complementary to or superior to the proposed reform policies should be considered.

Reformers should then describe the theoretical foundation of the reforms. Reasonable criticism of the models should be accepted for serious consideration. Incorrect criticism should be exposed and discarded. Critics offering alternative policies must also describe the theoretical foundation for their policies. Policies offered by critics who cannot or do not describe the theoretical foundation for their policies no longer have the right to continue as discussants. Policies with rigorous theoretical foundation must be considered. Policies with unsound theoretical foundation should be discarded.

Policy makers should then present the empirical evidence supporting the use of the post-Communist reform policies. Reasonable criticism of the evidence should be accepted; any policies, if proven to be without empirical foundation, should be scrapped. Fallacious criticism of the evidence should be exposed and discarded.

Critics offering alternative policies must also present the empirical evidence supporting their policies. Policies offered by critics who cannot or do not present evidence to adequately support their policies lose their right to continue as discussants. Policies with rigorous comprehensive empirical support must be considered. Policies not supported by comprehensive empirical evidence should be discarded.

Reformers then present the "map" of the reforms, showing what the policies will accomplish and when, and the potential problems that can be encountered. Reformers should identify which of the potential problems are part of the process, which problems the process of reforms will eliminate, and which problems need to be resolved; the map of the reforms must contain the solutions to these problems. Remaining critics should then be asked to present a map of their 
reforms. Those unable to provide a map lose their rights as a discussant.

This process -- allowing critics to present their views and policies, accepting reasonable proposals and criticism, and rejecting unreasonable proposals and criticism -- can improve reform policies and weaken the power of unreasonable criticism. For example, all proposals or criticisms, useful and deficient, will be on record. Later when people criticize the reforms unfairly or unreasonably, the record of their lack of substance and even their hidden agendas will diminish the power of their criticism.

One example of the power of unreasonable criticism is what happened in Mainland China in 1985. From 1979 to 1984, China had had five consecutive years of increased output due to the implementation of the "Household Responsibility System," (the government allowed households to "rent" plots of land for a fixed amount of output with any output in excess of that going to the households). Essentially, this reform re-linked reward to contribution. Thus, from 1979 to 1984, rice output increased by over 4\%/year while wheat production increased over 6\%/years; the GVAO [gross value of agricultural output] almost doubled in five years. Of all attempted economic reforms in Mainland China since 1949, this was the most successful. This was, perhaps, Mainland China's only truly successful economic reform since 1949.

In 1985, however, grain output decreased, giving hardliners the opening they had waited for to denounce Deng Xiao Ping and company. Hardliner Communists claimed that the decrease in grain output proved that the widely recognized and acclaimed success of the Household Responsibility System was actually a failure and that the professed success was nothing more than empty propaganda aimed at toppling Mao's beloved commune system. In December 1986, then Party General Secretary Hu, Yao Bang was removed from office, Zhao Zi Yang was moved from Premier to Hu's position as General Secretary of the Chinese party; Li Peng, a hardliner was promoted to Premier. In 1989, Zhao was put under house arrest after Deng ordered the massacres of the demonstrators in Beijing and other cities in Mainland China.

Deng, not being able to counter the criticism, had lost his monopoly on power. While Deng was still widely acknowledged as the "paramount leader" of Mainland China, his government had actually become a coalition government of economic reformers and hardliners.

What actually happened in 1985 was that the Household Responsibility System, a one-time structural change of agricultural land tenure, much superior to the commune system, had reached the plateau of this new agricultural production system. The decrease in grain output, the result of a drought and other weather conditions, was unrelated to the effectiveness of this reform. The Household-Responsibility-System reform had finished doing its job.

Criticism of Mainland China's Household Responsibility System, despite being unreasonable and wrong, had enough power to significantly slow the country's economic and political reforms which were the beginning of Mainland China's post-Mao transformation.

In Mainland China's case, if Deng and Company had made known in 1979 that the Household Responsibility System was a one-time structural change, and that grain output would eventually reach a new plateau rather than continue to increase by 4-6\%/year, and if Deng and Company had had a map of the reforms that foretold of possible decreases in grain output after the new plateau had been reached, then the unreasonable criticism of the Household-ResponsibilitySystem reform had failed would not have been able to materially affect Deng and Company's power.

Of course, not all criticism of reforms is unreasonable, but if the criticism is reasonable, what should be done? For example, suppose, after post-Communist reforms are implemented, unemployment rises as formerly state-owned factories fire redundant workers. Critics of the reforms can rightly complain that this is an economic problem; a classic example of this is Poland's $18.3 \%$ unemployment rate. Policy makers should agree that the increase in unemployment is indeed a problem, but point out that this problem was foreseen in the Map of Reforms, and that the solution to this problem is to increase aggregate demand with expansionary macroeconomic policies. In fact, reformers can say, "We have already began to raise government spending, lower taxes or decrease interest rates, and the unemployment problem will begin to decrease within six months and full employment will be reached within one year to 18 months. Of course, if this solution is incorrect and unemployment increases rather than decrease, then the reformers will be in trouble; they will and should 
lose their power.

During Boris Yeltsin's reign, many people complained about his policies. From 1992 to 1997, Russia's population had decreased by 4.2 million people. In August 1998, Russia's economy dove into a depression. The ruble depreciated from R6/US\$1 in January 1991 to R18/US $\$ 1$ from August 1998. Note that these are the "new" exchange rates instituted in early 1998. In "old" exchange rate terms, the exchange rate in 1998 would have been R18,000/US\$1, compared with R0.6/US\$1 (black market R15/US\$) in 1991.

So, how should have Yeltsin and other Russian policy makers react to this? First, this criticism is correct. Russia's economy has huge problems because of Yeltsin's and his cascade of Prime Ministers' and economic policies. So, his answer should have been, "You are right. We must change our policy." Then he should find the right economic policies to save Russia's economy.

If Yeltsin had tried to create a map of the reforms in 1992, that map should have shown that his reform policies would fail. Once he knew this he should have fired his economic advisors and changed those policies and. However, Yeltsin did not have the map, nor did he fully understand the effect that his reform policies would have on Russia's economy (to my knowledge current Russian President Putin does not have a map of the reforms). Yeltsin's political and economic problems stemmed from neither having the right policy goals or the policies which would bring economic prosperity to Russia; he didn't have a chance of successfully transforming Russia from a formerly economy into a viable economy. Bad economics is bad politics. Yeltsin was able to stay in office only by using the military and the police to sustain his power.

\section{The Implementation Of Reform Policies}

The procedure for implementing reforms polices are:

1. Implement these policies in a model economic zone or model city - proving grounds for proven policies." (Vladimir City under Mayor Igor Shamov was such a city, but it did not have the support of Russia's central government.)

2. If problems occur, make, if possible, necessary adjustments to the policies and retest them in the model economic zone.

3. If policies prove disastrous, then abandon them and design new policies.

4. Policies proven effective in the model economic zone can be implemented in other economic zones

5. Successful policies can then be implemented in regions and if still effective, implemented in the entire country.

With the right policy goals, the economic policies to achieve these goals and a map of the reforms, policy makers can begin to implement the policies. Thus, leaders need to be actively involved in the design and implementation of the economic reforms from the inception to the end. Despite this reasonable preparation, there is always a chance that the policies would fail. Moreover, even though the theoretically sound and empirically supported policies have worked elsewhere, they still may not work or work exactly the same in every post-Communist country, since each of these countries may have some unique conditions that might affect the policies' effectiveness. If the policies are immediately implemented in the entire country and if the policies fail, then the economic costs could be huge. This, in fact, was what did happen. In Russia, Central Europe and Central Asia the production foregone because of inept reform policies since 1992 probably exceed one trillion US dollars.

To minimize possible economic costs, the policies can be implemented in a "Model Economic Zone" or a "Model City" ("proving grounds for proven policies"). That is, the policies designed must have already been successful in country after country, time and again, year after year. Then they should be implemented in these proving grounds just to make sure that they work in local conditions. If they succeed, then they can be expanded to other zone and cities. If still successful, they can be installed in the entire nation.

The case of the Tianjin Economic/Development Zone [TEDA] is instructive. A US Government report [May 1986] reported the success of this zone, not in terms the quantity of its investment, but because the zone's young leaders 
understanding of international competition and the zone's administrators ability to offer the best investment climate in Mainland China. In August 1986, Deng and the other top 20 leaders of the country visited the zone. Then Premier Zhao $\mathrm{Zi}$ Yang lowered the interest rate charged the zone for development funds from 10.2\% to 2.4\%. In 1988, Motorola opened operations in TEDA with an investment of $\$ 120$ million, by far the largest single manufacturing joint venture in Mainland China. Motorola's total commitment in TEDA by 1996 was $\$ 1$ billion. By the end of 1996 , the zone had more than $\$ 10$ billion in committed investment, which is, to my knowledge the most foreign investment of any economic zone in the world at that time. In the past 20 years, TEDA's leadership has changed significantly. While TEDA had the opportunity to be a "proving ground for proven policies," the zone's primary goal today is to attract foreign investment rather than acting as the leading edge for Mainland China's economic reforms.

\section{CONCLUSION}

Post-Communist economic reforms in the former Soviet Union and Central Europe have failed miserably because, in the name of fighting inflation, they implemented contractionary economic policies that made the already dirtpoor formerly Communist economies even more poor. Despite these dismal results, some of these policies designers and implementers have characterized the results of their so-called reforms as "economic miracles"; meanwhile regime after regime were being voted out of office. In many Central European countries and republics of the Former Soviet Union, Communists or former Communists were voted back into office.

This article outlines the necessary and sufficient conditions for successful post-Communist reforms, beginning with the designing of theoretically rigorous policies and ending with the procedure for implementing the policies, first in "proving grounds for proven policies," and then only expanding the policies to larger regions if the policies are proven effective in bringing prosperity to the people of the proving grounds for proven policies. In answering the question, "How do you know if the policies will bring prosperity to the county?" The answer is that the policies are rigorous (designed specifically for the problems of post-Communist countries, mathematically correct and logically consistent, and proven to have been successful in bringing prosperity to countries time and again, year after year, and in country after country).

Very few countries in the world today are doing even moderately well economically. Ironically, the future world's non-Communist economies could depend significantly on the performance of post-Communist economies.

\section{BIBLIOGRAPHY}

1. Identity Politics and Economic Reform: Examining Industry. State Relations in the Czech and Slovak Republics Hilary Appel; John Gould, Europe-Asia Studies > Vol. 52, No. 1 (Jan., 2000), pp. 111-131

2. The EU and Recent Regional Reform in Poland, Martin Ferry Europe-Asia Studies > Vol. 55, No. 7 (Nov., 2003), pp. 1097-1116

3. Economic and Political Constraints during Transition, Stanislaw Gomulka, Europe-Asia Studies > Vol. 46, No. 1 (1994), pp. 89-106

4. Post-Communist Reforms: An Assessment, George Lee, Presented in IBER Conference, Las Vegas, Nevada (2006)

5. The Politics of Interest in Post-Communist East Europe, David Ost, Theory and Society > Vol. 22, No. 4 (Aug., 1993), pp. 453-485

6. The Dilemmas of Economic Liberalism in Poland, Ben Slay, Europe-Asia Studies > Vol. 45, No. 2 (1993), pp. 237-257

7. Thinging (sic) about Post-Communist Transitions: How Different Are They?, Sarah Meiklejohn, Terry, Slavic Review > Vol. 52, No. 2 (Summer, 1993), pp. 333-337

8. The Reassertion of the Left in Post-Communist Poland, Voytek Zubek, Europe-Asia Studies > Vol. 46, No. 5 (1994), pp. 801-837 


\section{NOTES}

